\title{
The Connection and Practical Exploration of the Cultivation of International Civil Engineers Under the Background of Belt and Road Initiative
}

\author{
Yanli $\mathrm{Wu}^{1, \mathrm{a}}$, Suhua Yin ${ }^{2, \mathrm{~b}}$, Chuangju $\mathrm{Wu}^{1}$ \\ ${ }^{1}$ Huanghe Jiaotong University, School of Traffic Engineering, Wuzhi Henan Province 454950, China \\ ${ }^{2}$ Hebei College of Technical and Industry, Shijiazhuang 050091, China \\ a1285691512@qq.com, bongzhongqi@126.com
}

\begin{abstract}
At present, Belt and Road Initiative's long-term strategic plan put forward by our country is being promoted and implemented methodically, and many countries along the route have also begun to enjoy the dividends brought about by Belt and Road Initiative's strategy. Infrastructure engineering construction is one of the important links in Belt and Road Initiative's early planning construction. A large number of engineering enterprises in our country have also gone out of the country to participate in the construction along the route, but at present, one of the difficult problems perplexing engineering construction enterprises is the extreme shortage of international civil engineers, which restricts the overall strategic process to a certain extent. Therefore, we should explore the connection mode and practice path of international civil engineering personnel training. Because the civil engineering specialty includes the above-ground or underground buildings, in addition to the building construction, the civil engineering specialty also includes the road, the bridge, the tunnel and the protective engineering and so on, thus knows that the civil engineering needs to pay more attention to the practicality. From the point of view of the overall connection mode framework, it is necessary to improve the teaching reform of relevant specialties in colleges and universities, increase the proportion of civil engineering practice teaching and improve the teaching ability of teachers. From the point of view of specific practical path, we should optimize the specific curriculum design (such as road survey design, bridge structure underground structure, etc.), curriculum proportion and promote the joint running of schools and enterprises, so as to accelerate the training of high quality and compound international civil engineer talents, so as to better serve the construction of Belt and Road Initiative.
\end{abstract}

Keywords: Belt and road initiative, Civil engineering, Talent training, Unicom, practice.

\section{Introduction}

From September to October 2013, General Secretary Xi Jinping put forward the cooperative initiatives for the construction of the New Silk Road Economic Belt and the 21st Century Maritime Silk Road, that is, Belt and Road Initiative's great strategic conception [1, 2]. The strategic planning of Belt and Road Initiative's regional economic development plays a very important role in promoting the growth of China's total economic volume and the economic and trade and cultural exchanges between countries along Belt and Road Initiative. Belt and Road Initiative is committed to the interconnection between countries in the Eurasian continent, the western Pacific region and the Indian Ocean region, in which the exchange and cooperation in infrastructure and civil engineering construction is the foundation and priority development area of Belt and Road Initiative's regional economic development, including railway, highway, airport, port, large-scale economic and trade center, logistics center and so on [3, 4]. The overall strategic planning and implementation of Belt and Road Initiative's inter-regional economic development has provided a stage for the majority of civil engineering professionals to carry out their talents, but the shortage of outstanding civil engineers is an indisputable fact [5], and has begun to restrict the progress of Belt and Road Initiative's foundation engineering and the realization of the future long-term strategy. Thus, it can be seen that whether Belt and Road Initiative's infrastructure strategy can be carried out smoothly is closely related to the training of civil engineers, but there are still serious problems in the training and practice of international civil engineers in China, which are mainly manifested in the following aspects. First of 
all, the current training mechanism of international civil engineers in China is not perfect. In Belt and Road Initiative's major infrastructure functional projects, compared with engineering quality, project cost, safety progress and other factors, most engineering construction enterprises have no time to take into account the training and exercise of civil engineers who have just entered the enterprise, but only do some basic talent recruitment, personnel performance evaluation and other conventional work, lack of overall strategic planning and implementation of talent training. From the point of view of the appointment authority of civil engineer posts and responsibilities, almost all of them are in the hands of project managers, and the appointment of engineering post personnel will inevitably have a certain subjective color. The arrangement of civil engineers lacks overall management, so it is impossible to make the best use of people. Thus, it can be seen that the lack of training mechanism of international civil engineers is one of the main factors causing the shortage of talents [6]. Secondly, the training methods of international civil engineers are backward and lack of the combination of theory and practice. The college students majoring in civil engineering who have just left the school only have certain theoretical knowledge, lack of understanding and application of engineering practice and theoretical knowledge. At present, the training of personnel for major construction projects is limited to the training of safety knowledge, theoretical knowledge and practical training.

\section{The Urgency and Importance of the Training of International Civil Engineering Talents under the Background of Belt and Road Initiative}

Belt and Road Initiative was put forward by General Secretary Xi from the perspective of the common development of regional economy and the building of a community with a shared future for mankind. His main purpose is to integrate the resources of countries along Belt and Road Initiative, learn from each other's strengths and make up for their weaknesses and develop together, so as to achieve win-win results in many ways. Belt and Road Initiative's great strategic conception is of great importance and urgency under the historical background of weak global economic growth. Most of the countries along Belt and Road Initiative are developing countries, and their economic development is relatively backward. It is also very urgent to establish an economic, trade and cultural community to realize the introduction of foreign construction capital and the input of domestic superior product resources. Belt and Road Initiative's strategy can not only deeply integrate the dominant resources of the countries along the route, but also give full play to the industrial advantages of various countries. At the same time, countries can share these superior resources on the basis of minimal investment in infrastructure construction, so as to maximize the interests of all parties. For the engineering construction enterprises in our country, it not only responds to the overall development strategy of the country "going out", but also brings new opportunities to the future development of the enterprises. Under the background of Belt and Road Initiative's good development, the standard operation of international civil engineering projects cannot be separated from high quality civil engineers. This kind of talents are a kind of compound and international talents, which need not only the guidance of professional theoretical knowledge of engineering construction, but also the continuous training and grinding in engineering practice. In order to meet the development requirements of internationalization of engineering enterprises, we should do a good job in the selection and training of subsequent reserve talents on the basis of the existing human resources of training enterprises, so that more young international civil engineers and newly graduated college students majoring in civil engineering can play a more important role in Belt and Road Initiative's international engineering. At present, the operation model of international civil engineering project objectively requires civil engineers to have rich engineering theoretical basis, practical experience and high work efficiency. With the gradual progress of Belt and Road Initiative's overall strategic planning, the cultivation of strategic talents with international civil engineers as the main body will become an important basic work and guarantee for the successful realization of Belt and Road Initiative's long-term plan. In Belt and Road Initiative's specific engineering project, how to build the team and how to arrange the department personnel can maximize the overall utility. These skills in the allocation and use of human resources will determine the success or failure of the project. China 
is the initiator and main organizer of Belt and Road Initiative's strategic planning. With the promotion of engineering projects, more enterprises will participate in international projects, and the demand for international civil engineering talents will continue to grow, so do a good job of civil engineering talents.

\section{Exploration on the Practice of Cultivating International Civil Engineering Talents under Belt and Road Initiative's Strategy}

Belt and Road Initiative's strategic conception is a complex system engineering. For international civil engineers, only with the following qualities can they meet the basic requirements of Belt and Road Initiative's international engineering project construction and the specific requirements of the international civil engineer's ability and accomplishment.

In order to meet the basic requirements of the project construction of the Belt and Road, the international civil engineering should have overall awareness, good communication ability, project management ability, engineering theoretical knowledge and certain engineering practice ability. Therefore, the training of qualified and excellent international civil engineers should pay special attention to the construction of the communication mode and the exploration of practice.

\subsection{The Connection Mode of International Civil Engineering Personnel Training}

As far as most enterprises in our country are concerned, the cultivation of basic talents still depends on colleges and universities at the present stage, and it is no exception for the enterprises that undertake Belt and Road Initiative's engineering project. After higher education, college students have the basic theory knowledge related to engineering construction, but there are still serious deficiencies in the cultivation of students' practical ability in the current higher education in our country. Especially for civil engineering majors with high practical ability, they lack the support of practical ability, which makes it difficult for these graduates to enter the job role quickly after entering the enterprise. This is because the major of civil engineering involves very high practical application courses, such as bridges, road buildings, etc., which are closely related to safety, and because of the different architectural styles, structural requirements and soil geological conditions in different environments, strong practical experience is required in the actual work position, so the theoretical knowledge cannot be "copied" to the practical application, so if students can only learn theoretical knowledge while in school, Then it cannot fully apply the theory to different practical application environments. The connection mode of international civil engineering personnel training is to change and adjust the teaching mode of civil engineering specialty in colleges and universities, and increase the proportion of practical courses, so that the civil engineering talents trained by colleges and universities have initially met the basic requirements of engineering construction practice and can better serve Belt and Road Initiative's engineering construction. The connection mode of international civil engineering personnel training begins with the training of civil engineering talents in colleges and universities, realizes the seamless connection between the teaching of theoretical knowledge in colleges and universities, the practice training in university classroom and the practice training in engineering enterprises, and can enable the graduates of civil engineering students to complete the transformation from college students to international civil engineers in the fastest time. The main characteristics of this kind of talent training connection mode are shown below.

First of all, the relevant syllabuses of colleges and universities majoring in international civil engineering should be adjusted moderately, because civil engineering projects not only require civil engineers to have a profound theoretical basis, but also require them to combine engineering theory with construction practice, and to independently undertake, design and supervise the process of the project. In the aspect of overall curriculum design, the density and progress of the original syllabus should be improved, that is, the teaching task of engineering construction theory should be completed in the first two academic years, while the graduation design, practical links and enterprise practice should be carried out in the last two academic years. Taking the road engineering in the branch of civil engineering as an example, during the teaching period of university schools, the first two years 
are mainly used to inculcate the theoretical basis, so as to promote students to have a general understanding of the historical evolution, development status and possible problems of road engineering. In the last two years of school life, the emphasis of teaching should be shifted to practice, leading students to different road construction sites for field exploration and understanding the details in the process of practical application. In the process of training international civil engineers, theoretical teaching and practical teaching should not be separated, but the two should be integrated teaching, so that students can more firmly master the theoretical knowledge of engineering construction. In the aspect of choosing the specific mode of talent training and connectivity, according to the basic requirements of Belt and Road Initiative's engineering construction, we should focus on the construction of two basic platforms, such as the theoretical teaching platform and the practical teaching platform of higher education, so as to consolidate the theoretical foundation and improve the practical ability of college students in teaching.

Secondly, the Unicom training mode of international civil engineers needs to be supported by practice, including the practical curriculum arrangement of college graduates in the school stage, graduation practice and enterprise practice and so on. As far as the major of road engineering is concerned, the practical courses in the school stage can include road engineering simulation. By using computer, students can truly understand the characteristics of all kinds of roads, simulate the actual working conditions of different roads, such as material, structure, terrain and so on. Under the condition of practice, learning the knowledge of engineering can better master the engineering construction theory. This case-based teaching mode, which shows the engineering mechanics, building code and technical standard learned by students, is an important step in the transformation from civil engineering college students to international civil engineers. At the same time, the practical teaching method can also sum up all kinds of problems in the teaching task from the practice classroom, such as how to carry on the road construction under different terrain conditions, whether the scheme is feasible and so on, so that the student group can better understand the development trend of the industry. While emphasizing practical teaching, for students who have completed the study of professional theory courses, the school is responsible for organizing these students to practice in engineering construction units, promoting students' field investigation, understanding the problems and solutions that may occur in the actual road construction, and so on, so as to prepare for entering the actual work position.

Third, in the practice exploration of the international civil engineering personnel training connection mode, it also includes the construction of the teaching staff, because the construction of the university teachers' team is also one of the core problems related to the training and reserve of engineers. In order to accomplish the teaching task better, the civil engineering teachers should be encouraged to train in the civil engineering enterprises and improve the comprehensive ability of practical teaching in colleges and universities. For example, teachers of in-service road engineering major are encouraged to participate in practical engineering projects, and teachers' practical construction ability is enhanced, so that teachers can share their experience to the group of students, thus further increasing students' practical experience. The Unicom mode of international civil engineering talent training under the background of Belt and Road is a comprehensive talent training mode across institutions of higher learning and engineering construction enterprises, which will be more conducive to the rapid transformation of the role of university graduates and can provide a strong international reserve of civil engineers for Belt and Road system engineering.

\subsection{The Practical Path of Cultivating International Civil Engineering Talents}

The communication model of international civil engineering personnel training in the background of the one-way environment provides a macro and long-term development planning and logical framework for the training and storage of engineering-based talents, and in the specific training practice path exploration, It mainly includes the integration of experimental resources in the course of higher learning, the improvement of the specific gravity of practice teaching and the enhancement of the strength of the training of the enterprises. 
First of all, from the point of view of civil engineering majors in colleges and universities, it is necessary to optimize the existing teaching curriculum and integrate experimental hardware facilities and other teaching resources. For civil engineering, which requires higher teaching practice, it is necessary to appropriately reduce the proportion of basic courses and public courses, and increase the proportion of professional courses and practical courses in order to improve students' professional ability. The training of international civil engineers cannot be completed overnight, but a spiral gradual training model. For such practical subjects as civil engineering, it is also necessary to increase the input of hardware resources in experimental teaching. Specifically, it includes building a professional integrated platform of experimental teaching. However, the teaching resources and capital investment in colleges and universities are limited, so the existing teaching resources can be integrated, such as the redistribution of resources in the laboratories of many science and engineering disciplines, and the establishment of a multifunctional comprehensive laboratory for the sharing of multi-disciplinary experimental resources. At present, VR technology has developed to a high level. Based on VR technology, the actual situation of simulation engineering site can be simulated, so that students majoring in civil engineering can better understand and apply the theoretical knowledge of civil engineering in the virtual simulation environment.

Secondly, colleges and universities majoring in civil engineering should continue to increase the proportion of experimental teaching courses. They can not only stay in books with the theoretical knowledge they have learned, encourage students majoring in civil engineering to step out of the classroom and enter the field of laboratory and engineering construction. Only by combining civil engineering theory with engineering practice can the transformation from civil engineering graduates to international civil engineers be realized as soon as possible. The compound talents with both solid theoretical knowledge and engineering practice ability are the talents really needed in Belt and Road Initiative's engineering construction.

Third, it is necessary to strengthen the training of international civil engineers by industry and engineering enterprises. The ultimate goal of cultivating civil engineering talents in colleges and universities is to provide the overall strategic service of engineering construction enterprises and Belt and Road Initiative. Moreover, colleges and universities are limited by the overall teaching tasks and educational funds of the school. The cultivation of engineering practice ability of civil engineering graduates is only in a primary stage, and the more standardized engineering practice operation also needs to be unified vocational training and skill training by the enterprise after entering the post. In order to improve the training progress and efficiency of international civil engineers, engineering construction units and colleges and universities can adopt a directional school-enterprise joint international civil engineering personnel training method. Under the guidance of this kind of joint training mode, the school and enterprise jointly formulate the concrete scheme of oriented training of civil engineering talents.

\section{Summary}

The strategic concept of the regional coordination and development of the Belt and Road is a major strategic decision on the vital interests of the countries along the line under the new historical conditions of the general secretary of Xi Jinping, as the country and the regional power of the strategy of the Belt and Road. It is supposed to make due contributions to the development of the regional economy and the improvement of the living standards of the peoples along the line. In the infrastructure construction of the one-way strategy, the construction enterprises of our country have played an irreplaceable role, but many problems have also been exposed in the construction of the project, among which the most important and urgent problems are the shortage of international civil engineering talents. To solve the problem of the cultivation of the special talents of the international civil engineering, we should start with the existing human resources of the whole engineering enterprise to solve the problem of the burning of the engineering construction enterprise, but also from the perspective of the long-term, we should set out from the angle of the special cultivation of 
the talents of the university and the joint of the school and the enterprise. The training is both a solid theoretical foundation and an international civil engineering talent with a certain practical ability.

\section{Acknowledgements}

This work is supported by Fund Project: Henan soft Science Research Project (192400410033).

\section{References}

[1]. Sheng Bin, Guo Ting. Belt and Road Initiative and apec regional economic cooperation [J]. The Asia-Pacific Economy, 2017(2):7-12+175.

[2]. Li Qinzhu, Dong Youde. "Belt and Road Initiative" Initiative and APEC Regional Economic Cooperation[J]. Statistics \& Decision, 2018, 34(12):107-110.

[3]. Yang Ya-nan, Ali Mujiang. The relationship between urban traffic dominance and regional economic development level in the background of "One Belt and One Road" [J]. The Geography in the Arid Area, 2017, 40(3):680-691.

[4]. Jia Ruining, $\mathrm{Xu}$ Haicheng. Adaptability of Expressway scale to Regional Economic Development: an empirical Analysis based on Provincial Panel data of China from 2001 to 2015 [J]. China's Circulation Economy, 2017, 31(7):20-29.

[5]. Cui Deqin, Peng Junzhi. A probe into the training Mode of career-oriented talents for Applied undergraduate Civil Engineering Specialty: a case study of Civil Engineering Specialty in Jilin Institute of Agricultural Science and Technology [J]. Vocational and Technical education, 2017, 38(20):29-32.

[6]. Sha Yong. Research on the mode of civil engineering and personnel training - Evaluation of the Theory and Practice of the Reform of Civil Engineering and Construction Education[J]. a newslover, 2017(12):119-119.

[7]. Xiao Jing, Fan Xiaochun. Tamping the training link to improve the student's engineering quality comprehensively. Take civil engineering as an example[J]. High-Level Engineering Education Research, 2017(04):83-85+164. 